\title{
Recycling Nonmagnetic Material from De-sulferization Slag as Coarse Aggregate through Cold-Pressing Technique
}

\author{
Chih-Ta Tsai, ${ }^{1, *}$, Chia-Cheng $\mathrm{Wu}^{2}$, Teng-Ker $\mathrm{Hsu}^{2}$, and Juu-En Chang ${ }^{3}$ \\ 1 Sustainable Environment Research Laboratories, National Cheng Kung University, Tainan 70955, Taiwan \\ 2 R\&D Department, CHC Resources Corporation, Kaohsiung 81260, Taiwan \\ 3 Department of Environmental Engineering, National Cheng Kung University, Tainan 70100, Taiwan \\ E-mail: *chihta.tsai@gmail.com (Corresponding author)
}

\begin{abstract}
Every year there was approximately 500,000 tons of de-sulferization slag generated in Taiwan, but the recycling amount was very slightly. A new approach, the cold-pressing technique that incorporates the principles of the cement chemistry and composite material was developed to recycle innocuous resources (e.g. construction residual soil, granite and lime sludge, and sediment, etc.) as recycling coarse aggregate. Even this technique also has successfully been applied to recycle stainless steel reductive slag with low volume stability. This paper aims to show that using cold-pressing technique can recycle nonmagnetic material from de-sulferization slag as coarse aggregate. Herein the cement-based composite is regarded as concrete. Particularly, the mixture proportions with a low cement amount of $100 \mathrm{~kg} / \mathrm{m}^{3}$ and more than $70 \%$ (by weight) of nonmagnetic material from de-sulferization were designed. The test results show that the specific gravity of recycling coarse aggregate is about 1.67 in the OD state; the absorption capacity is $27.65 \%$; the dry loose density (i.e. unit weight) is about $1,106 \mathrm{~kg} / \mathrm{m}^{3}$; and other characteristics conform to ASTM C33. Therefore the cold-pressing technique is a new and practicable approach to recycle nonmagnetic material from de-sulferization slag in future.
\end{abstract}

Keywords: Recycling, cold-pressing technique, nonmagnetic material from desulferization slag, coarse aggregate.

ENGINEERING JOURNAL Volume 20 Issue 4

Received 3 March 2016

Accepted 13 June 2016

Published 1 August 2016

Online at http://www.engj.org/

DOI:10.4186/ej.2016.20.4.163 


\section{Introduction}

The attention of shortage of the primitive aggregate has been received in Taiwan. Although the natural resource is rather lack, the recycling resources are quite plentiful (e.g., construction residual soil, reservoir sediments, industrial by-products, and so on). Every year there was about 500,000 ton of de-sulferization slag generated by China Steel Corporation, but the recycling amount is very slightly in Taiwan. Due to the fact that de-sulferization slag has the characteristic of poor volume stability (i.e. de-sulferization slag is liable to react with $\mathrm{H}_{2} \mathrm{O}$ and $\mathrm{CO}_{2}$ to result in expansion). Based on the purposes of green building materials (i.e. reduction of waste and $\mathrm{CO}_{2}$ footprint, energy conservation, lightening of material, and so on) [1], it is a critical issue to treat the wastes properly and encourage the recycling of resources. Many research studies indicate that the sintering technique has been successfully applied to recycle a lot of resources as light weight aggregates [2]. However, the energy consumption and $\mathrm{CO}_{2}$ emission from this sintering process are too high to be extensively adopted. A new approach, the cold-pressing technique [3] which incorporates the principles of the cement chemistry [4-5] and composite material [6] was developed to recycle these resources as recycling coarse aggregate. Consequently, the main difference between cold-pressing and sintering technique is the reduction of energy consumption and $\mathrm{CO}_{2}$ footprint. This paper aims to show that using cold-pressing technique to recycle nonmagnetic material from de-sulferiztion slag as coarse aggregate and properties of these recycling coarse aggregate.

\section{Experimental}

\subsection{Materials}

The following were used as cementitious materials in this study: Type I Portland Cement produced by Taiwan Cement Company, blast-furnace slag (BF slag) provided by CHC Resources Corporation, and class F fly ash supplied by Taiwan Power Station. A carboxylate-based type G superplasticizer was purchased from local factory. The cementitious materials and superplasticizer conform to the related ASTM standards. The glass fibers were recycled from printed circuit board (PCB) wastes by Much Fortune Technology Co., Ltd. The nonmagnetic material from de-sulferization slag treated by CHC Resources Corporation was different from traditional de-sulferization slag. Table 1 and Table 2 show that compositions and toxicity characteristic leaching procedure (TCLP) results of nonmagnetic material from de-sulferization slag, respectively. The TCLP results of nonmagnetic material from de-sulferization slag were below the criteria of general enterprise wastes and green building materials in Taiwan as shown in Table 2.

Table 1. Compositions of nonmagnetic material from de-sulferization slag, $\%$.

\begin{tabular}{ccc}
\hline & PL-1 & PL-2 \\
\hline $\mathrm{MgO}$ & 3.57 & 2.96 \\
$\mathrm{Al}_{2} \mathrm{O}_{3}$ & 5.32 & 5.22 \\
$\mathrm{SiO}_{2}$ & 11.72 & 12.81 \\
$\mathrm{SO}_{3}$ & 4.71 & 3.71 \\
$\mathrm{Na}_{2} \mathrm{O}$ & 0.15 & 0.20 \\
$\mathrm{~K} 2$ & 0.07 & 0.10 \\
$\mathrm{CaO}$ & 62.88 & 65.01 \\
$\mathrm{MnO}$ & 0.80 & 0.60 \\
$\mathrm{Cr}_{2} \mathrm{O}_{3}$ & 0.10 & 0.04 \\
$\mathrm{Fe}_{2} \mathrm{O}_{3}$ & 9.48 & 7.70 \\
\hline
\end{tabular}

\subsection{Mixture Proportioning}

In this study a local mixture proportion method in Taiwan, densified mixture design algorithm (DMDA) [7], is adopted to design and prepare the cement-based composite for making the recycling coarse aggregate. Herein the cement-based composite is regarded as concrete. In order to minimize the shrinkage rate or the expansion rate and ensure the durability of recycling coarse aggregate, a very low water-to-cementitious ratio $(\mathrm{w} / \mathrm{cm})$ of 0.20 was selected to design mixture proportions of cement-based composite. And a total of 
$39.4 \mathrm{~kg}$ glass fibers (the volume $=0.02 \mathrm{~m}^{3}$ ) was added to the cement-based composite to reach the intended design value of $2.0 \%$ by volume for preventing crack generations and enhancing the toughness as well as volume stability [8-9] of cold-pressing recycling coarse aggregate. In view of cement has the most energy consumption and $\mathrm{CO}_{2}$ emission in all constituent materials of recycling coarse aggregate, the mixture proportions with a low cement amount of $100 \mathrm{~kg} / \mathrm{m}^{3}$ was designed as shown in Table 3 . Also Table 3 shows that the cement-based composite contains more than $70 \%$ (by weight) of nonmagnetic material from de-sulferiztion slag.

Table 2. TCLP test results of nonmagnetic material from de-sulferization slag, $\mathrm{mg} / \mathrm{L}$.

\begin{tabular}{lcccccccccc}
\hline & $\mathrm{Cr}$ & $\mathrm{Ba}$ & $\mathrm{Se}$ & $\mathrm{Cd}$ & $\mathrm{Pb}$ & $\mathrm{Cu}$ & $\mathrm{As}$ & $\mathrm{Hg}$ & $\mathrm{Ag}$ & $\mathrm{Cr}^{+6}$ \\
\hline PL-1 & 0.07 & 0.543 & $\mathrm{ND}$ & $\mathrm{ND}$ & $\mathrm{ND}$ & $\mathrm{ND}$ & $\mathrm{ND}$ & $\mathrm{ND}$ & $\mathrm{ND}$ & $\mathrm{ND}$ \\
PL-2 & 0.05 & 0.298 & $\mathrm{ND}$ & $\mathrm{ND}$ & $\mathrm{ND}$ & $\mathrm{ND}$ & $\mathrm{ND}$ & $\mathrm{ND}$ & $\mathrm{ND}$ & $\mathrm{ND}$ \\
$\begin{array}{l}\text { Criteria of general } \\
\text { enterprise wastes }\end{array}$ & 5.0 & 100.0 & 1.0 & 1.0 & 5.0 & 15.0 & 5.0 & 0.2 & 5.0 & 2.5 \\
$\begin{array}{l}\text { Criteria of green } \\
\text { building material }\end{array}$ & - & - & - & 0.3 & 0.3 & 0.15 & 0.3 & 0.005 & 0.05 & 1.5 \\
\hline
\end{tabular}

Table 3. Mixture proportions of cement-based composites for granulation, $\mathrm{kg} / \mathrm{m}^{3}$.

\begin{tabular}{lcccc}
\hline Cement & $\begin{array}{c}\text { Pozzolanic } \\
\text { materials }\end{array}$ & $\begin{array}{c}\text { Nonmagnetic material } \\
\text { from de-sulferiztion slag }\end{array}$ & Glass fiber & SP+Water \\
\hline 100 & 290 & 1,171 & 39.4 & 78.0 \\
$(6.25)$ & $(18.10)$ & $(73.19)$ & $(2.46)$ & \\
\hline
\end{tabular}

Pozzolanic materials: BF slag + Fly ash

( ): The percentage by weight of solid composition materials

\subsection{Method of Granulation}

Three various methods were adopted to form the cold-pressing recycling coarse aggregate [3]. They are: 1) spirally push method; 2) immediately squeeze out method; 3) press ingot method. The granulating energy of spirally push method is too small to adequately form the recycling aggregate while the cement-based composite with lower moisture. The cement-based composite with higher moisture could be granulated by using spirally push method, but the produced recycling aggregate will not have appropriate properties. Regardless of nonmagnetic material from de-sulferiztion slag with moisture, the immediately squeeze out method will cause the water within cement-based composite to be drained out during the process of granulating recycling coarse aggregate (like consolidation in geotechnical engineering [10]). Therefore the immediately squeeze out method cannot be employed to form the cold-pressing recycling coarse aggregate. Finally, the press ingot method was developed to successfully granulate the cold-pressing recycling coarse aggregates with five various diameters (i.e. $24,18,12,8$, and $5 \mathrm{~mm}$, respectively) as shown in Fig. 1.

\subsection{Testing Program}

After granulating, these cold-pressing recycling coarse aggregate was cured in saturated limewater at the temperature of $23 \pm 2.0^{\circ} \mathrm{C}$ according to ASTM C192. Because the recycling coarse aggregate has five various particle diameters, the gradation of recycling coarse aggregate was established by the abovementioned five various diameter particles according to the mean of the upper and lower limit from size number 56 and 6 recommended by ASTM C33. The cylindrical cold-pressing recycling coarse aggregate with diameter of $24 \mathrm{~mm}$ was conducted single particle compressive strength test at the age of $3,7,14,28$, 56, 91, 180, and 365-d, respectively. After the age of 28-d, they also were conducted basic property tests (e.g., specific gravity, absorption capacity, dry loose density, and so on) according to the related ASTM standards. 

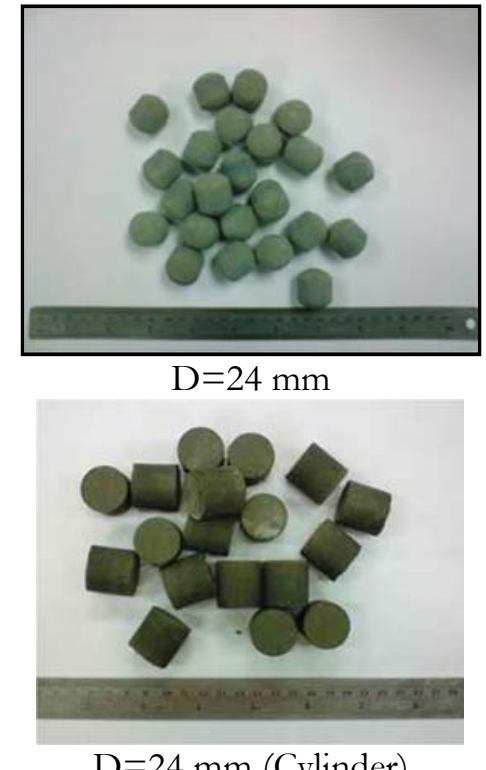

$\mathrm{D}=24 \mathrm{~mm}$ (Cylinder)
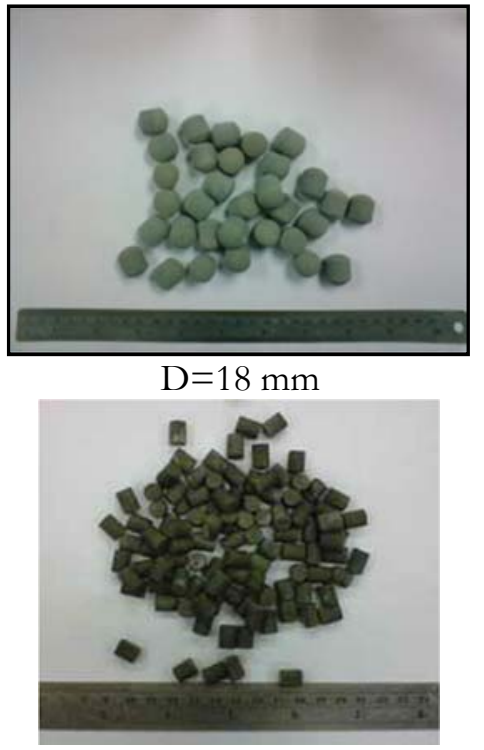

$\mathrm{D}=8 \mathrm{~mm}$
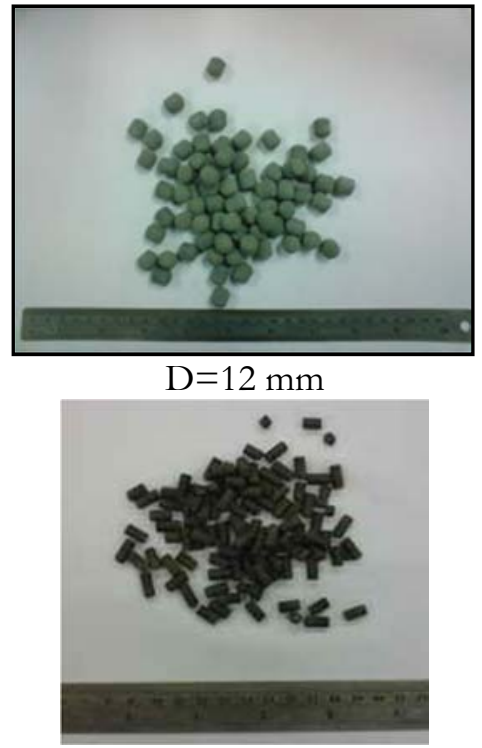

$\mathrm{D}=5 \mathrm{~mm}$

Fig. 1. Photos of cold-pressing recycling coarse aggregate.

\section{Results and Discussion}

\subsection{Moisture of Nonmagnetic Material from De-sulferiztion Slag under Granulating}

The nonmagnetic material from de-sulferiztion slag was regarded as primitive aggregate in concrete while designing the mixture proportions of cement-based composite for granulating the recycling coarse aggregate. But the properties of nonmagnetic material from de-sulferiztion slag are quite different from primitive aggregate (e.g. particle shape, gradation, absorption, and so on). The purpose of exploring the optimum moisture of nonmagnetic material from de-sulferiztion slag under granulating aggregate is to avoid two issues: 1) With lower moisture: the recycling coarse aggregate cannot be adequately granulated; 2) With higher moisture: the redundant water may drain out during the process of forming recycling aggregate (like consolidation in geotechnical engineering [10]) to result in the excessively high water-to-cement ratio (w/c) or water-to-cementitious materials $(\mathrm{w} / \mathrm{cm})$ around the surface of the recycling aggregate. The excessively high $\mathrm{w} / \mathrm{c}$ or $\mathrm{w} / \mathrm{cm}$ will be harmful to the strength, hardness, abrasion resistance, soundness, permeability, etc. [4-5].

The optimum moisture for recycling nonmagnetic material from de-sulferiztion slag as coarse aggregate through cold-pressing technique was $22.5 \%$ while the stress of granulation by using press ingot method is 35.0 to $42.0 \mathrm{MPa}$. This result also implies that the cold-pressing technique is able to be applied to handle recycling resources with moisture and reduce the energy consumption and $\mathrm{CO}_{2}$ emission resulted from the oven-dry process.

\subsection{Observation of Volume Stability}

The traditional de-sulferization slag always contains $\mathrm{f}-\mathrm{CaO}$ that is liable to react with $\mathrm{H}_{2} \mathrm{O}$ and $\mathrm{CO}_{2}$ to result in the reusing or recycling products occurring expansion, split, or even rupture. This study used the treated nonmagnetic material from de-sulferization slag by CHC Resources Corporation that was different from traditional de-sulferization slag. The variations (e.g. split or expansion) of recycling aggregate surface were observed every day before the age of $10-\mathrm{d}$ as well as 14-d, 28-d, 56-d, 91-d, 180-d, and 365-d so as to evaluate its volume stability. The results of volume stability observation show that the surface of recycling aggregate didn't have any slight splits due to expansive reaction of $\mathrm{f}-\mathrm{CaO}$ within nonmagnetic material from de-sulferization slag before the age of 10 days. So far, the recycling coarse aggregate with nonmagnetic material from de-sulferization slag also had no further expansion, splits, or even rupture for more than one year as shown in Fig. 2. 


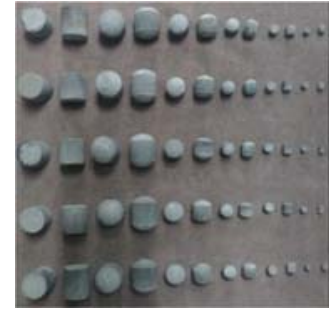

PL-1 (3-d)

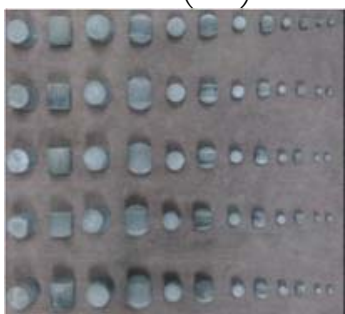

PL-2 (7-d)

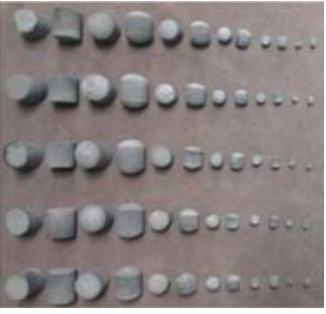

PL-1 (10-d)

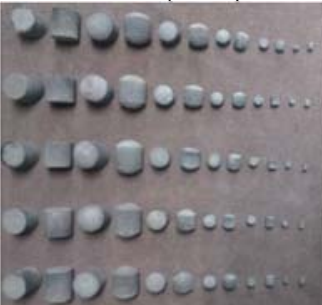

PL-2 (28-d)

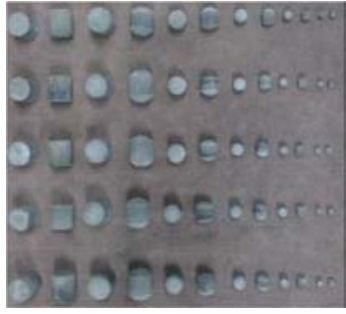

PL-1 (180-d)

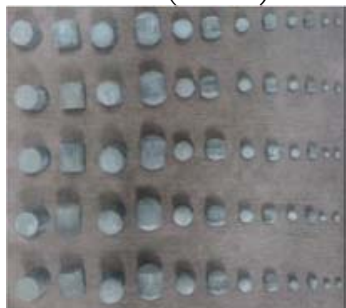

PL-2 (365-d)

Fig. 2. The volume stability observation results of recycling coarse aggregate.

\subsection{Single Particle Compressive Strength}

Referring to ASTM C39, the cylindrical cold-pressing recycling coarse aggregate with diameter of $24 \mathrm{~mm}$ was conducted single particle compressive strength test at the age of 3, 7, 14, 28, 56, 91, 180, and 365-d, respectively. Fig. 3 shows the growth of single particle compressive strength of cold-pressing recycling coarse aggregate with nonmagnetic material from de-sulferiztion slag. The result indicates that the single particle compressive strength increases with the increase of curing age due to the fact that the contribution of hydration of cement and pozzlanic reaction [4-5]. The strength efficiency of cement implies the yielded strength per kilogram of cement and denoted as $\mathrm{MPa} / \mathrm{kg}$ or psi $/ \mathrm{kg}$. Fig. 4 shows the strength efficiency of cement of cold-pressing recycling coarse aggregate at $28-\mathrm{d}$ and $180-\mathrm{d}$ is in excess of $0.14 \mathrm{MPa} / \mathrm{kg}$ and 0.22 $\mathrm{MPa} / \mathrm{kg}$, respectively. The strength efficiency of cement at $180-\mathrm{d}$ is 3 times higher than that of traditional concrete $(0.07 \mathrm{MPa} / \mathrm{kg})$ and even is 3.5 times at $365-\mathrm{d}$. Such result also proves that the cold-pressing technique has the characteristics of low energy consumption and low $\mathrm{CO}_{2}$ emission. The Fig. 3 and Fig. 4 also show that the nonmagnetic material from de-sulferization slag treated by CHC Resources Corporation was quite stable.

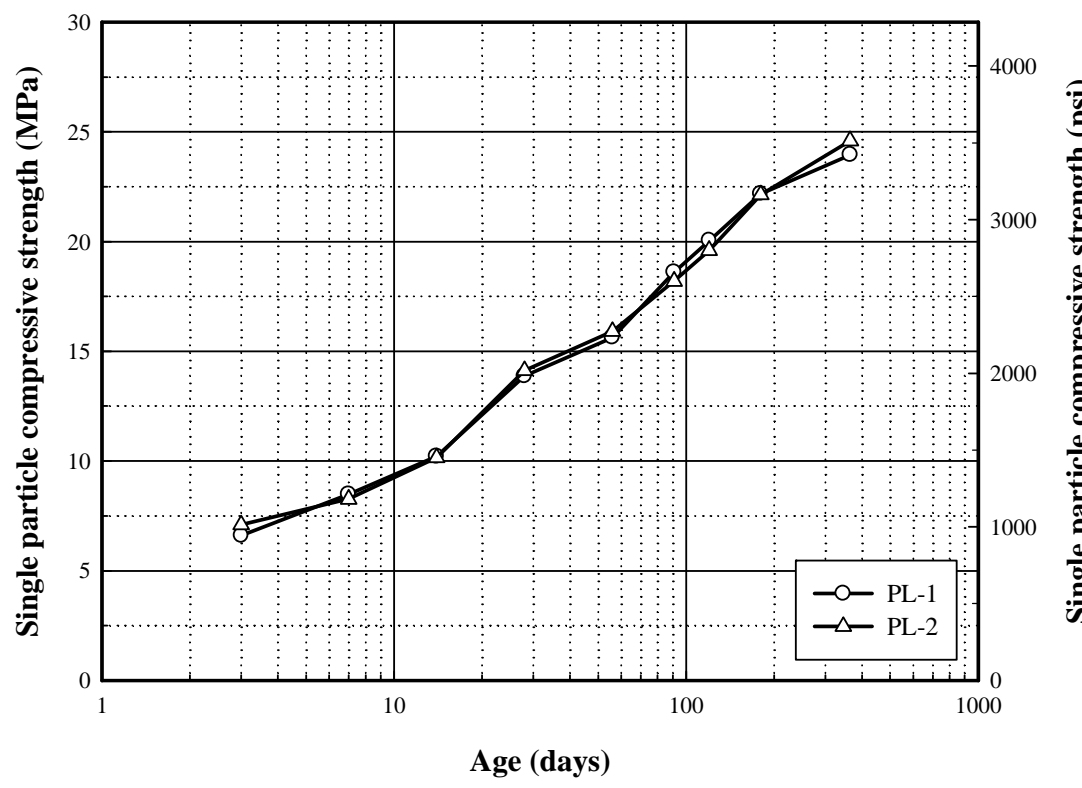

Fig. 3. The single particle compressive strength growth of recycling coarse aggregate. 


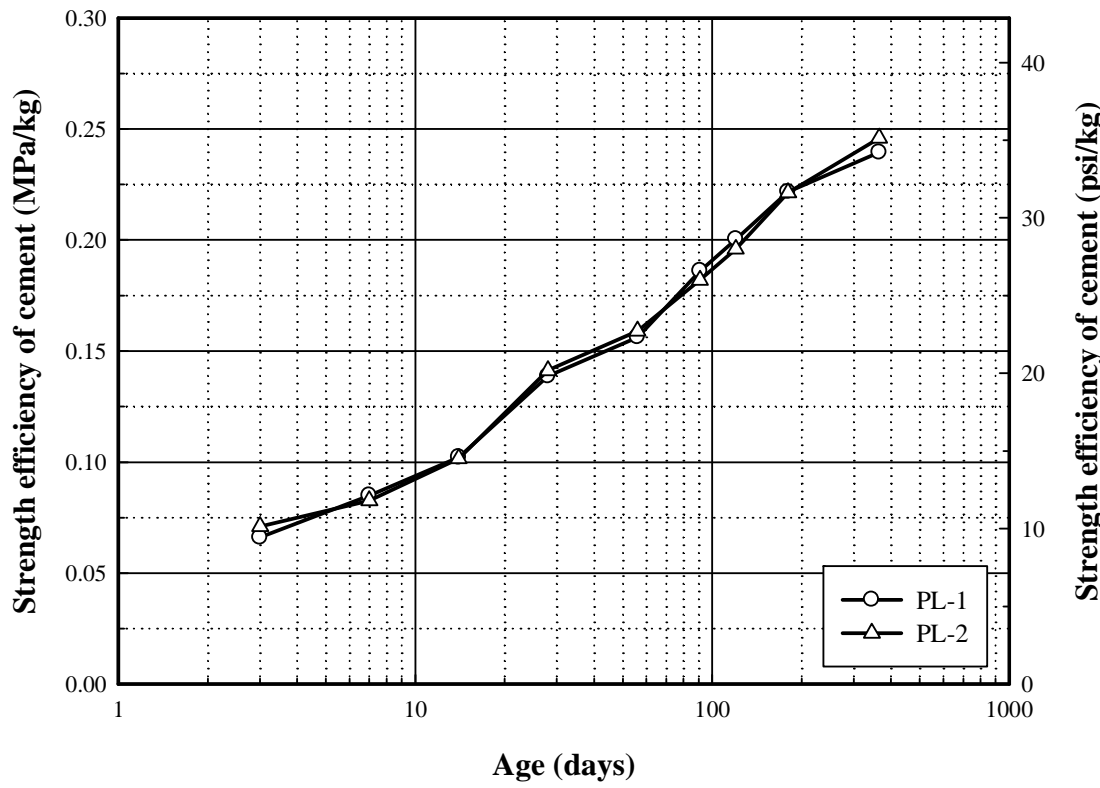

Fig. 4. The strength efficiency of cement growth of recycling aggregate.

\subsection{Basic Properties of Recycling Coarse Aggregate}

After granulating the cold-pressing recycling coarse aggregates by the press ingot method, these recycling aggregates are cured in saturated limewater at the temperature of $23 \pm 2.0^{\circ} \mathrm{C}$ according to ASTM C192. According to the related ASTM standards, basic property tests (e.g., specific gravity, absorption capacity, dry loose density, and so on) were conducted after the age of 28 days. The results show that the specific gravity of recycling coarse aggregate is about 1.67 in the OD state and 1.92 to 1.93 in the saturated-surfacedry (SSD) state; the absorption capacity is $27.65 \%$; the dry loose density (i.e. unit weight) is about 1,106 $\mathrm{kg} / \mathrm{m}^{3}$; the voids is 33.6 to $33.7 \%$; other characteristics also conform to ASTM C33 as shown in Table 4.

Table 4. Basic properties of recycling coarse aggregate.

\begin{tabular}{|c|c|c|c|c|c|}
\hline & \multicolumn{2}{|c|}{ Specific gravity } & \multirow{2}{*}{$\begin{array}{c}\text { Absorption } \\
(\%)\end{array}$} & \multirow{2}{*}{$\begin{array}{l}\text { Unit weight } \\
\left(\mathrm{kg} / \mathrm{m}^{3}\right)\end{array}$} & \multirow{2}{*}{$\begin{array}{c}\text { Voids } \\
(\%)\end{array}$} \\
\hline & OD & SSD & & & \\
\hline PL-1 & 1.68 & 1.93 & 27.63 & 1,105 & 33.6 \\
\hline PL-2 & 1.67 & 1.92 & 27.67 & 1,107 & 33.7 \\
\hline \multirow[t]{2}{*}{ Standards } & ASTM C127 & ASTM C127 & ASTM C127 & ASTM C29 & ASTM C29 \\
\hline & $\begin{array}{l}\text { Clay lumps } \\
\text { and friable } \\
\text { particle }\end{array}$ & $\begin{array}{l}\text { Materials } \\
<75 \mu \mathrm{m}\end{array}$ & $\begin{array}{c}\text { Coal and } \\
\text { lignite }\end{array}$ & Abrasion & Soundness \\
\hline PL-1 & ND & $0.11 \%$ & ND & $27.6 \%$ & 4.83 \\
\hline PL-2 & ND & $0.10 \%$ & ND & $28.2 \%$ & 4.74 \\
\hline $\begin{array}{l}\text { Criteria of } \\
\text { ASTM C33 }\end{array}$ & 2.0 to $10.0 \%$ & $1.0 \%$ & 0.5 to $1.0 \%$ & $50.0 \%$ & $12.0 \%$ \\
\hline
\end{tabular}

\subsection{Comparisons of Various Aggregates}

According to an approach to estimate energy consumption, $\mathrm{CO}_{2}$ emission, and prime cost of sintering recycling aggregate [11], the cold-pressing recycling aggregate also was evaluated and compared with primitive and sintering aggregate. Table 5 shows the comparisons of properties, energy consumption, $\mathrm{CO}_{2}$ emission, and prime cost of three various type aggregates (i.e. primitive, sintering, and cold-pressing recycling aggregates). The results show that the recycling aggregate produced by using cold-pressing technique can reduce about $65 \% \mathrm{CO}_{2}$ footprint than using sintering technique [11]. The prime cost of sintering recycling aggregate is 4 to 6 times higher than cold-pressing recycling aggregate. Even if the prime 
cost of cold-pressing recycling aggregate is lower than the primitive aggregate in Taiwan. It is worth mentioning that the gradation of cold-pressing recycling aggregate is controllable and this characteristic will be helpful for application in concrete.

Table 5. Comparisons of various type aggregates.

\begin{tabular}{cccc}
\hline Item & & Aggregate type & \\
& Primitive & Sintering & Cold-pressing \\
\hline Gradation & Incontrollable & Single size & Controllable \\
Abrasion $(\%)$ & $8-35$ & - & $27.6-28.2$ \\
Soundness $(\%)$ & $<12$ & - & $4.74-4.83$ \\
Energy consumption & Low & High & Low \\
$\mathrm{CO}_{2}$ emission $\left(\mathrm{kg} / \mathrm{m}^{3}\right)$ & - & 62.89 & 20.59 \\
Cost $\left(\mathrm{NTD} / \mathrm{m}^{3}\right)$ & $450-900$ & $3,500-5,000$ & 800 \\
\hline
\end{tabular}

\section{Conclusions}

1) The DMDA is appropriate to design the cement-based composite with nonmagnetic material from desulferiztion slag for producing the cold-pressing recycling coarse aggregate. And the cement-based composite contains more than $70 \%$ (by weight) of nonmagnetic material from de-sulferiztion slag.

2) The cold-pressing technique was successfully adopted to recycle nonmagnetic material from desulferiztion slag as coarse aggregate. The proposed stress of granulation by using press ingot method is 35.0 to $42.0 \mathrm{MPa}$ and the corresponding optimum moisture for granulating recycling coarse aggregate with nonmagnetic material from de-sulferiztion slag is $22.5 \%$. This result also implies that the coldpressing technique is able to be applied to handle recycling resources with moisture and reduce the energy consumption and $\mathrm{CO}_{2}$ emission resulted from the oven-dry process.

3) The single particle compressive strength of cold-pressing recycling coarse aggregate with nonmagnetic material from de-sulferiztion slag increases with the increase of curing age due to the fact that the contribution of hydration of cement and pozzlanic reaction.

4) At the age of 365-d the strength efficiency of cement of cold-pressing recycling coarse aggregate is 3.5 times higher than that of traditional concrete $(0.07 \mathrm{MPa} / \mathrm{kg})$. Such result also proves that the coldpressing technique has the characteristics of low energy consumption and low $\mathrm{CO}_{2}$ emission.

5) The test results of single particle compressive strength also imply that the nonmagnetic material from de-sulferization slag treated by CHC Resources Corporation was quite stable.

6) After evaluating and comparing with primitive and sintering aggregate, the recycling coarse aggregate produced by using cold-pressing technique can reduce about $65 \% \mathrm{CO}_{2}$ footprint than using sintering technique as well as the prime cost of cold-pressing recycling aggregate is 4 to 6 times lower than sintering recycling aggregate. Therefore the cold-pressing technique is a new and practicable approach to recycle nonmagnetic material from de-sulferiztion slag in future.

\section{Acknowledgement}

The authors greatly appreciate the grant from Architecture and Building Research Institute, Ministry of Interior and Ministry of Economic Affairs (101-EC-17-A-10-S1-187), CHC Resources Corporation and National Science Council (NSC 102-2221-E-006-245), Taiwan, R.O.C. The continuous supports and technical assistances of The Performance Experiment Center, Building Research Institute, Ministry of The Interior, R.O.C. are gratefully acknowledged. 


\section{References}

[1] M. C. Ho et al., "Recycling green building material," in Evaluation Manual for Green Building Material, 2015 new ed. Taipei, Taiwan: ABRI, Ministry of the Interior, 2015, ch. 6, pp. 49-58.

[2] M. F. Hung, and C. L. Hwang, "Study of fine sediments for making lightweight aggregate," Waste Manage. Res., vol. 25, no. 5, pp. 449-456, 2007.

[3] C. T. Tsai, "Cold-bonding technique - a new approach to recycle innocuous construction residual soil, sludge, and sediment as coarse aggregates," in Sintering of Ceramics - New Emerging Techniques, 1st ed. Rijeka, Croatia: InTech, 2012, ch. 5, pp. 95-120.

[4] S. Mindess, and J. F. Young, Concrete, N. J.: Prentice-Hall Press, 1981.

[5] P. K. Mehta, Concrete-structure, properties and materials, N. J.: Prentice-Hall Press, 1986.

[6] R. F. Gibson, Principles of composite material mechanics, Singapore: McGraw-Hill Press, 1994.

[7] P. K. Chang, Y. N. Peng, and C. L. Hwang, "A design consideration for durability of highperformance concrete," Cem. Concr. Compos., vol. 23, no. 4-5, pp. 375-380, 2001.

[8] C. T. Tsai, L. S. Li, C. C. Chang, and C. L. Hwang, "Durability design consideration and application of steel fiber reinforced concrete in Taiwan," Arab. J. Sci. Eng., vol. 34, no. 1B, pp. 57-79, 2009.

[9] C. T. Tsai, G. T. C. Kung, and C. L. Hwang, "Use of high-performance concrete on rigid pavement construction for exclusive bus lanes," Constr. Build. Mater., vol. 24, no. 5, pp. 732-740, 2010.

[10] R. D. Holitz, and W. D. Kovacs, An introduction to geotechnical engineering, N. J.: Prentice-Hall Press, 1981

[11] J. P. Shiao, C. L. Hwang, and C. P. Pan, "The Economic Evaluation of the Application of the Lightweight Aggregate Concrete on RC Structure," Taipei, Taiwan: ABRI, Ministry of the Interior, 2002. 